\title{
Impact of Brand on Rural and Urban Consumer Behavior- A Study on Mobile Phone Buyers
}

\author{
Shaktiman Singh ${ }^{1}$, Saurabh Kumar ${ }^{2}$, Tanmay Goel $^{3}$, Sahib Chawla ${ }^{4}$ \\ ${ }^{1,2,3,4}$ Department of Mechanical Engineering, Delhi Technological University, India
}

\begin{abstract}
Consumers are the backbone of all business organizations \& coherently all business activities concern with consumer and consumer satisfaction.Brand acts as a signal allowing customer to quickly recognize a product as they are familiar with or one they like.The powerful brand is which resides in the mind of the consumer.This paper examines how the rural and urban population conceive the notion of "BRAND". The research aims at comparing the buying behavior of rural \& urban consumer \& find out their priorities while making a purchase decision regarding mobile phones.This study has been conducted through literature study as well as a questionnaire administered survey of 200 respondents of different age groups, income \& occupation and has been analyzed through AHP (Analytical Hierarchy Process) to comply with the objectives \& also to draw conclusions. The study reveals that the urban consumer is more brand and style 'conscious' compared to its rural counterpart which prioritizes functionality and price more. It also shows that urban population relies majorly on internet as source of information whereas rural population relies on T.V. ads\& Mobile phone retailers. This paper serves as a valuable guideline for management to review their advertising campaigns \& modify their mobiles according to the need of the customer.
\end{abstract}

Keywords: AHP, Advertising, Brand management, Consumer Behavior, Mobile Phones.

\section{Introduction}

Although mobile phones have become a fundamental part of personal communication across the globe during the past ten years, consumer research has devoted little specific attention to motives and choice underlying the mobile phone buying decision process. There are numerous complex factors that need to be taken into account when exploring mobile phone buying decision process, including both macro and microeconomic conditions $^{[1]}$ that affect the evolution of mobile phone market in general and individual consumer's motives and decision making in particular. The individual and environmental factors influences the consumer behavior. Often, consumer in India purchases the goods and services, which they want, others to accept. Behavior is therefore determined by the individual's psychological makeup and the influence of other. Thus behavior is the result of interaction of the consumer \& personal influence and pressure exerted upon them by outside forces in the environment ${ }^{[2]}$. An understanding of buying behavior is essential in marketing and planning programs. Acomprehensive research of consumer behaviorgives the advertiser a deeper insight of his target section of market, which in turn proves to be very significant in strategic advertising decisions, especially in defining the target markets and creating the advertising appeal and message. Modern Urban buyers along with the product features also want to know how and why the product will benefit them. They look not only for what a product can do but also what it means to them. Thus, buying behavior involves a complicated series of stimulus and response. The mobile phone itself has also become a totemic and fashion object, with users decorating, customizing, and accessorizing their mobile phones to reflect their personality. In the rationale of modern marketing, the firm's existence is dependent on customer's satisfaction. Therefore, the knowledge of "what the customer thinks" and "what consequently would contribute to his satisfaction" is at the requirement of the marketer ${ }^{[3]}$.

Usage of cell phones is not restricted to urban talk and educated youth. Brands evolve to keep up with changing demographics, changing spending habits, consumer lifestyles, and various ethnicities becoming more prevalent. Indian Marketers on rural marketing have two understanding- (i) The urban metro products and marketing products can be implemented in rural markets with some or no change. (ii) The rural marketing required the separate skills and techniques from its urban counterpart.

The Marketers have following facilities to make them believe in accepting the truth that rural markets are different in so many terms.

(i) The rural market has the opportunity for many brands.

(ii) Low priced products can be more successful in rural markets because the low purchasing, purchasing powers in rural markets.

(iii) Rural consumers have mostly homogeneous group with similar needs, economic conditions and problems. 
(iv) The rural markets can be worked with the different media environment as opposed to press, film, radio and other urban centric media exposure.

How reality does affect the planning of marketers? Do villagers have same attitude like urban consumers? The question arises for the management of rural marketing effects in a significant manner so than companies can enter in the rural market with the definite goals and targets but not for a short term period but for longer duration. In this research paper, we will discuss the role of regard. The strategy, which will be presented in the paper, can be either specific or universally applicable.

\section{Purpose Of The Research}

This research is designed to investigate the influence of Brand name \& Advertisements on two different sections of society-the urban $\&$ the rural consumer base respectively.Essentially the research aspires to study the topic through reviewing related articles \& also by getting the perceptions of knowledgeable individuals regarding the topic through surveys. Moreover, this study will focus on the following goals:

- To study the significant difference, if any, in the purchasing motive, preferences, taste of the urban \& rural consumer.

- To know about the awareness level of consumer regarding 'Brands'.

- To identify and analyze the difference in the factors which impinge on to the satisfaction level of both types of consumers.

- To make suggestions on the basis of findings.

\section{Research Methodology}

This survey was conducted at two places. For the study of rural and urban areas, we surveyed Saket (South Delhi) and Ballabgarh (Faridabad). Total 200 people were surveyed, out of which 100 people belonged to each region. The sample space included both men and women of different age groups. Depending upon the age the sample is divided into 3 groups: 12-18,19-21 and 21 above. By studying different age groups, the study aims to find the consumer behavior about brand recognition for different age groups. The study is simplified by the use of pie charts wherever necessary and the results are expressed in the form of percentages. It is assumed that all the respondents are not related to each other in any manner and the opinions of one respondent cannot affect the opinions of any other respondent.

\section{Hypotheses}

1. The level of awareness of 'Branded 'products among the customers is average.

2. Brand image \& Advertisement has significant relationship with consumer buying behavior.

\section{Objectives Of The Study}

This study was carried out with the following objectives:

1. The study aims at comparing the preference for brand recognition among urban and rural mobile users.

2. The study aims to compare the role of advertisement in the purchase of mobile phone among rural and urban mobile users.

3. The study aims to compare the preference of brand recognition among different income groups among the respondents.

4. The study aims to compare preference of functionality, quality and price over brand recognition among rural and urban mobile users.

5. The study aims at finding the most preferable mobile brands among rural and urban mobile users.

\section{Problem Statement}

In present times, "Brand name" is emerging out to be one of the strongest marketing tool in all fields.Narrowing down our view to mobile phones, we can see that Brand Image plays a significant role in customer decision making process.But due to lack of technological advancements, $60 \%$ of total population residing is rural areas is still deprived of this "Notion" as compared to their urban counterparts. The present study made an attempt to investigate the influence of Brand image and advertisement on both urban and rural sections of the Indian society. 
Impact of Brand on Rural and Urban Consumer Behavior-A Study on Mobile Phone Buyers

VII. Division Of Sample Space

\begin{tabular}{|c|c|c|c|}
\hline $\begin{array}{c}\text { Division On The } \\
\text { Basis Of }\end{array}$ & $\begin{array}{c}\text { Division Characteristic Of The } \\
\text { Respondent }\end{array}$ & \multicolumn{2}{|c|}{ Area To Which The Respondent Belongs } \\
\hline & & URBAN & RURAL \\
\hline & $12-18$ & 11 & 24 \\
AGE & $19-21$ & 66 & 17 \\
\hline \multirow{2}{*}{ SEX } & Above 21 & 23 & 84 \\
& Male & 67 & 16 \\
\hline \multirow{3}{*}{ FAMILY INCOME } & Female & 33 & 21 \\
& Below 15000 & 15 & 41 \\
\hline
\end{tabular}

VIII. Observations And Results

- The ownership of different mobile brands among rural and urban users.

\begin{tabular}{|c|c|c|}
\hline BRAND & URBAN & RURAL \\
\hline SAMSUNG & 29 & 30 \\
\hline NOKIA & 11 & 28 \\
\hline SONY & 25 & 9 \\
\hline APPLE Iphon & 13 & 3 \\
\hline BLACKBERRY & 2 & 2 \\
\hline HTC & 6 & 20 \\
\hline MICROMAX & 10 & 3 \\
\hline KARBONN & 1 & 2 \\
\hline OTHERS & 3 & \\
\hline
\end{tabular}

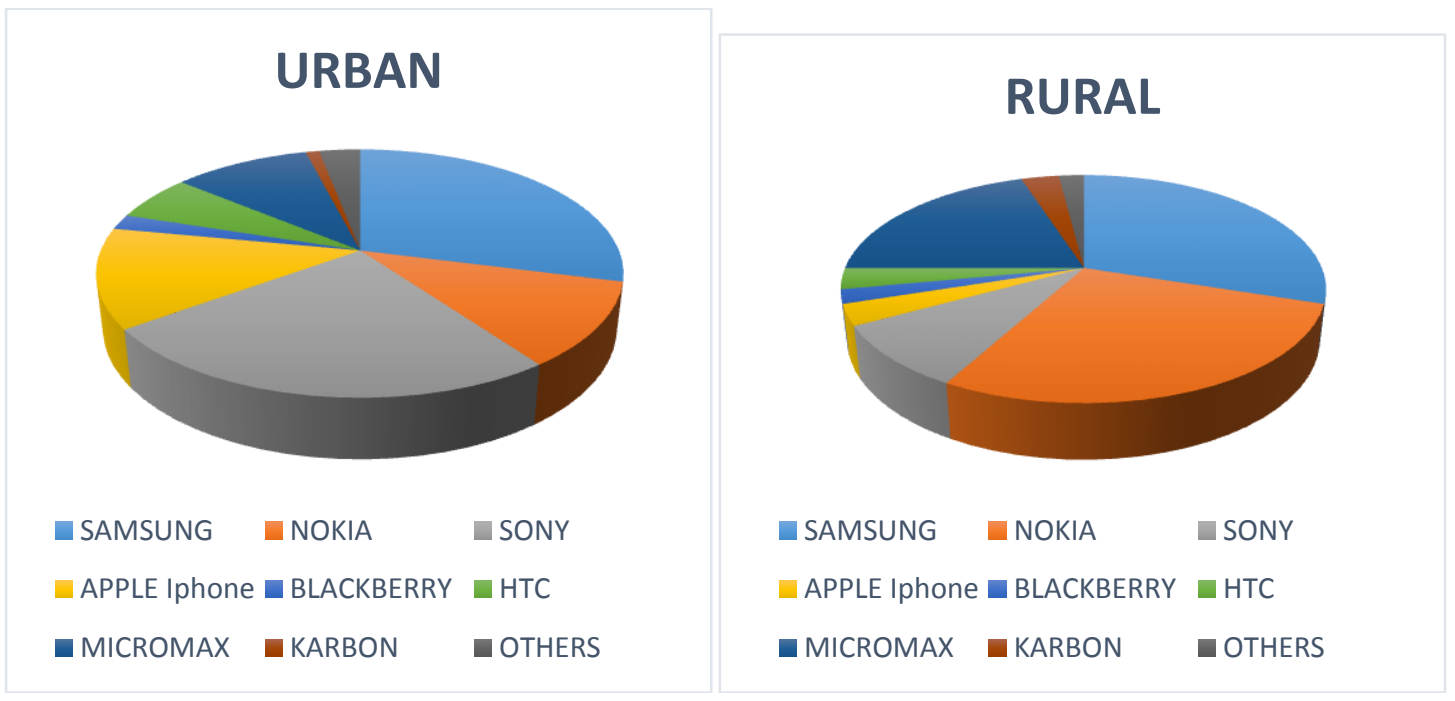

- Source of information about the product.

\begin{tabular}{|c|c|c|}
\hline VARIABLE & URBAN & RURAL \\
\hline T.V. & 35 & 54 \\
\hline NEWSPAPER & 11 & 23 \\
\hline FRIENDS & 26 & 9 \\
\hline INTERNET & 23 & 11 \\
\hline OTHER & 5 & 3 \\
\hline
\end{tabular}




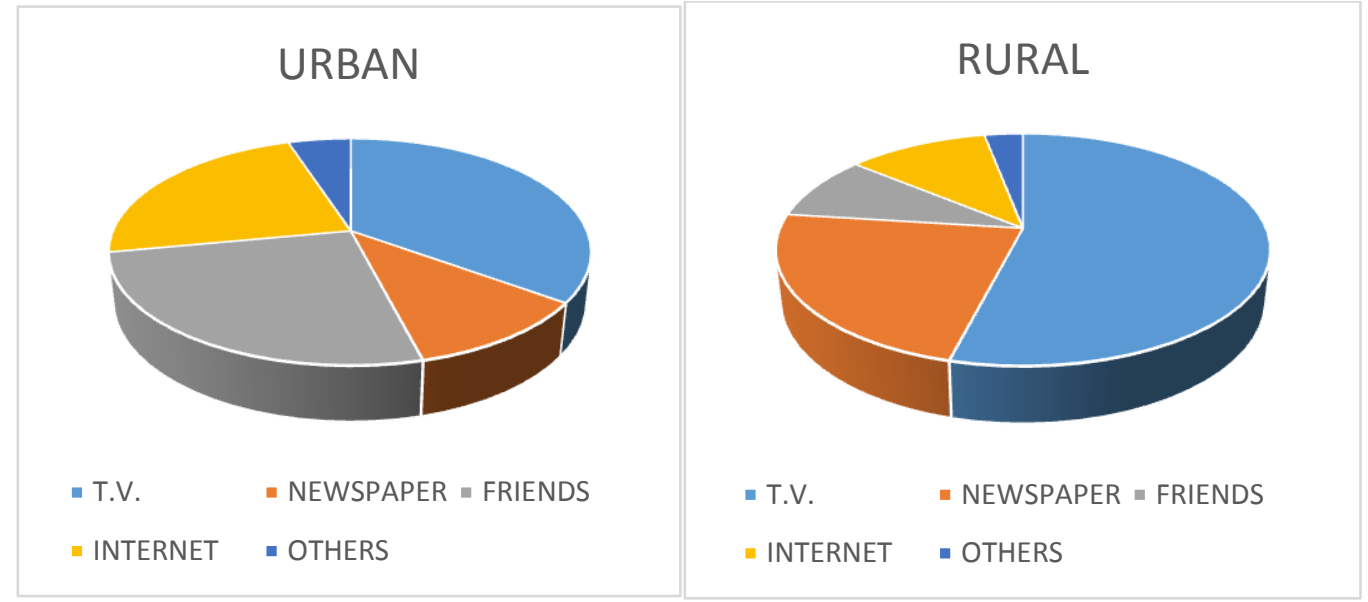

- The selection of mobile phone after considering its brand (on basis of demographic factor)

\begin{tabular}{|c|c|c|}
\hline Response & \multicolumn{2}{|c|}{ Respondent } \\
\hline YES & Urban & Rural \\
\hline NO & 76 & 51 \\
\hline MAYBE & 13 & 37 \\
\hline
\end{tabular}
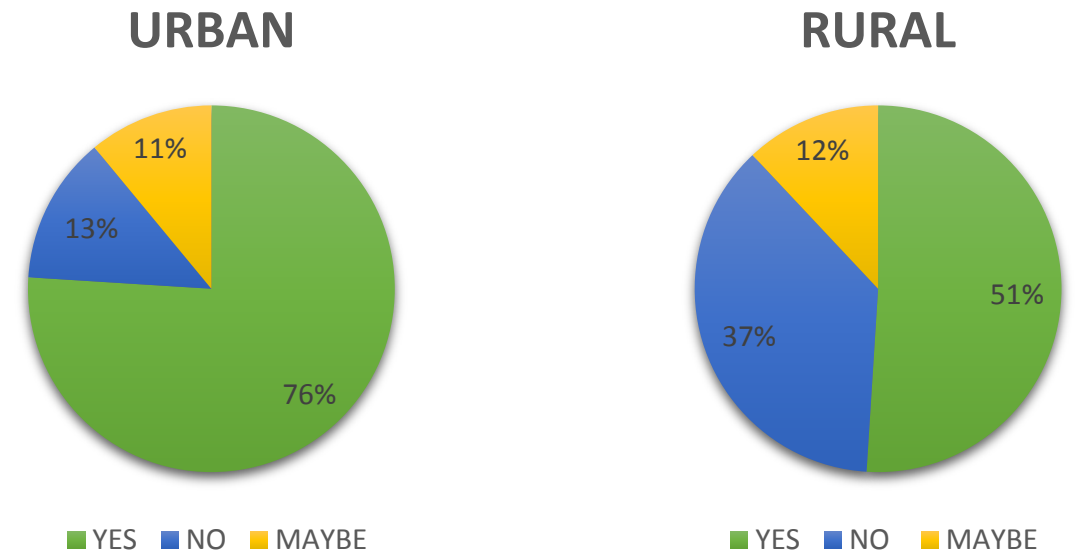

- The selection of mobile phone after considering its brand(on basis of income factor)

\begin{tabular}{|c|c|c|c|}
\hline INCOME & RESPONSE & \multicolumn{2}{|c|}{ RESPONDENT } \\
\hline (per month) & & URBAN & RURAL \\
\hline \multirow{3}{*}{ BELOW 15000} & YES & 9 & 4 \\
\hline & NO & 4 & 17 \\
\hline & MAYBE & 2 & 0 \\
\hline \multirow{3}{*}{$15000-35000$} & YES & 31 & 21 \\
\hline & NO & 7 & 12 \\
\hline & MAYBE & 5 & 8 \\
\hline \multirow{3}{*}{ ABOVE 35000} & YES & 36 & 26 \\
\hline & NO & 2 & 8 \\
\hline & MAYBE & 4 & 4 \\
\hline
\end{tabular}

- The most important factor to be considered while selecting a mobile phone.

\begin{tabular}{|c|c|c|}
\hline VARIABLE & \multicolumn{2}{|c|}{ RESPONDENT } \\
\hline & URBAN & RURAL \\
\hline Functionality & 51 & 44 \\
\hline Brand & 21 & 12 \\
\hline Pricing & 15 & 24 \\
\hline Quality & 13 & 20 \\
\hline
\end{tabular}



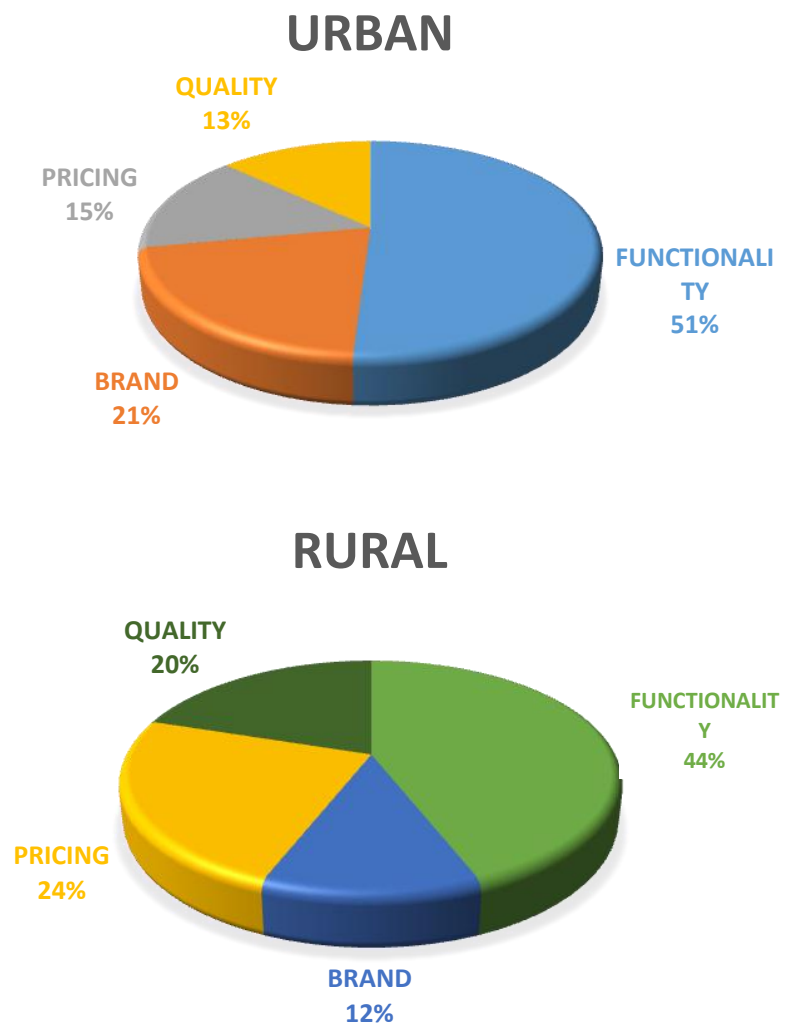

- Ownership of a new mobile phone.

\begin{tabular}{|c|c|c|}
\hline VARIABLE & \multicolumn{2}{|c|}{ RESPONDENT } \\
\hline NEW PHONE & URBAN & RURAL \\
\hline SECOND HANDPHONE & 91 & 21 \\
\hline
\end{tabular}

\section{Major Findings}

- As high as $76 \%$ of the total urban respondents say that they would consider a key brand in the market for purchase of a mobile phone. Surprisingly, a healthy $51 \%$ of the rural respondents feel the same way.

- Most of the respondents from urban as well as rural areas admit that the source of information about the product they bought was T.V. advertisement.

- As expected, as the purchasing power of the buyer increases, the preference for branded products increase for both rural and urban users increases. This is mainly due to the increase in the quality of lifestyle.

- For both urban and rural users, functionality is a key trait in a mobile phone that they consider before buying a mobile phone followed by its price. It can be concluded that people a willing to spend more money to buy a mobile phone with better specifications.

- For both urban and rural users, Samsung and Nokia are preferred over other brands. This may be due to the fact that these companies offer mobile phones for every price range so that each section of society can be targeted, unlike Apple Iphone, which is owned by only a bunch of people in urban areas only. Also the brands like Micromax and Karbonn which offer high specifications for low prices are also catching up in the market.

\section{Significance Of The Study}

This study helps firms and organizations to improve their market strategies by understanding issues like:

1. How the psychology of an urban differs from rural consumers i.e. how they think, feel, reason $\&$ select among different alternatives (e.g. brand, product etc.) 
2. How both consumers are influenced by his/her environment (e.g. culture, family, signs, media etc.)

3. How limitation in consumer knowledge \& information processing abilities influence decision making \& marketing

4. How companies can adapt \& improve their marketing campaigning by adjusting to the difference in needs of rural \& urban consumers.

\section{Conclusion}

The purpose of this paper was to study the influence of brand name on the consumer decision making process and to investigate the effect of external factors on consumer behavior by comparing the choices of two different consumer bases- rural and urban. Consumer behavior is a conditioned response to external events, therefore the region and surrounding environment also have some impact on choice of consumer.To conduct the research, a questionnaire administered survey has been conducted among 200 respondents of urban and rural regions and the data revealed that brand name has strong influence on purchase decision. In rural areas, pricing is given more consideration than brand name, while in urban areas, brand name overtakes pricing factor. From the study it is also clear that well known mobile phone brands are equally popular among the people of both regions and the consumers trust the brand name. The company which offers a wide range of options to choose from is more likely to successfully gain popularity and capture market share equally well in urban as well as rural areas. The study highlights the key elements which influence the consumer behavior and can prove to be valuable to mobile phone companies as well as market analysts.

\section{References}

[1] HeikkiKarjaluoto, Factors Affecting Consumer Choice of Mobile Phones: Two Studies from Finland, Journal of Euro marketing, Vol. 14(3) 2005

[2] Dr. PratyushTripathi\& Prof. Satish Kr. Singh, An Empirical Study of Consumer Behavior towards The Preference and Usage of Mobile Phone Services in Bhopal, Current Trends in Technology and Sciences Volume : 1, Issue : 2 ,Sept. 2012

[3] Jegan, A. And Dr. S. Sudalaiyandi, Consumer Behavior Towards Mobile Phone Services In Kovilpatti, Thoothukud District (India) - A Case Study by, International Journal of Current Research, Vol. 4, Issue, 04, pp.261-265, April, 2012

[4] Karjaluoto, H., J. Karvonen, et al. (2005). Factors affecting consumer choice of mobile phones: two studies from Finland. Journal ofEuro marketing 14(3): 59-82.

[5] Bettman, J.R. and Zins, M.A. (1977), “Constructive Processes in Consume Choice”, Journal of Consumer Research, 4, September, pp. 75-85.

[6] Sun, T. and G. Wu (2004). Consumption patterns of Chinese urban and rural consumers.Journal of Consumer Marketing21(4):245253.

[7] Keller, K. L., (2008) Strategic Brand Management, Second Edition, Prentice Hall of India, New Delhi.

[8] Gosh, Aparisim, 'The New Rules of Rural Marketing', Business World, April, 1994

[9] Alba, J.W. and Hutchinson, J.W. (1988), "Dimensions of Consumer Expertise", Journal of Consumer Research, 13, March, pp. 411 454.

[10] Rogers M.J 1988. "Expenditures of rural and urban consumers”, Monthly Labour Review, Vo.41

[11] Blythe, J. 2006 Essentials of Marketing Communications. 3rd Edition Pearson Education Limited. Essex (UK)

[12] Stayman, D.M. and Deshpande, R. (1989), "Situational Ethnicity and Consumer Behavior", Journal of Consumer Research, 16, December, pp. 361-371.

[13] Nithila Vincent, A Study on Brand Consciousness Among Children and its Effect on Family Buying Behavior in Bangalore City, Indian Journal of Marketing, Volume XXXVI • Number $1 \cdot$ January 2006

[14] Schmitt, B. H. \& Pan, Y. (1994). Managing corporate and brand identities in the Asia-Pacific region. California Management Review, 36 (4), 32-48.

[15] Nedungadi, P. (1990). Recall and consumer consideration sets: Influencingchoice without altering brand evaluations. Journal of Consumer Research, 17(3), 263-276.

[16] Dr. L. Shashikumar SharmaAn Empirical Study of Consumer Behavior in Mobile Phone Market in Bhutan Management Convergence, Vol 1, No 1 (2010)

[17] V. AlaguPandian et al. An Empirical Study of Consumer Behavior towards the Preference and Usage of Mobile Phone Services in Bhopal IJRFM Volume 2, Issue 3 (March 2012)

[18] Dr. HeenaUpadhyay et al. Consumer Expenditure Behavior in India: A Case of Rural and Urban Consumer International Journal of Business and Management InventionVolume 2 Issue 2 (February. 2013)

[19] Schiffman and Kannuk, Consumer Behavior, Pearson 4th edition, (1991)

[20] Home N (2002). "Rural consumers' patronage behavior in Finland", International Review of Retail, Distribution and Consumer Research, pp.149-164.

[21] Sampath Kumar Ravikanthi. Indian urban and rural market: a comparative study on place of purchase in selected consumer products, International Trade \& Academic Research Conference (ITARC), 7 - 8th November, 2012, London.UK. 